\title{
Studies on lipid digestion in the preruminant calf. The source of lipolytic activity in the abomasum
}

\author{
By JOYCE TOOTHILL, S. Y. THOMPSON AND J. D. EDWARDS-WEBB \\ National Institute for Research in Dairying, Shinfield, Reading RG2 ${ }_{9} A T$
}

(Received 6 Fanuary 1976 - Accepted 23 March 1976 )

\begin{abstract}
r. Lipolytic and proteolytic activities and $\mathrm{pH}$ values were determined in secretions collected from innervated abomasal pouches and in abomasal contents from preruminant calves given liquid diets.

2. No lipolytic activity was detected in pouch secretions collected during $\mathrm{I} h$ after feeding, though lipolytic activity was present in abomasal contents; pepsin $\left(E C_{3}\right.$.4.23. I) and rennin $(E C 3.4 .23 .4)$ were present in both pouch secretions and abomasal contents. The $\mathrm{pH}$ values of pouch secretions ranged from $I \cdot 2$ to $I \cdot 8$ and those of abomasal contents from $4 \cdot 2$ to $5 \cdot 9$.

3. When diet was placed directly into the abomasal pouch soon after feeding, the $\mathrm{pH}$ values of pouch and abomasal contents decreased similarly (i.e. from 6.3 to approximately 5 ). Protease activity (U/ml) of pouch contents ranged from 0.1 to 0.8 and that of abomasal contents from 0.1 to $\mathbf{0} 2$. No lipolytic activity was detected in pouch contents, though abomasal contents contained 0.6 to $\mathrm{I} \cdot 2 \mathrm{U} / \mathrm{ml}$ and when the diet contained milk-fat as the dietary fat source considerable lipolysis of triglycerides containing shorter-chain fatty acids was found.

4. It is concluded that there is no significant secretion of lipolytic enzymes by the fundal mucosa and that the lipolysis of triglycerides in the abomasum of the preruminant calf is due predominantly to a lipolytic enzyme in saliva.
\end{abstract}

Lipolysis of triglycerides occurs in the stomachs of several species and this has given rise to the postulate that gastric secretions contain a lipase $(E C$ 3.1.1.3). However, lipolytic activity in stomach contents could derive not only from gastric mucosal secretion but also from saliva and regurgitated duodenal contents. Working with preruminant calves, Ramsey \& Young (I96I) and Otterby, Ramsey \& Wise $(1964 a, b)$ compared the extent of lipolysis of whole-milk diets given either orally or introduced directly into the abomasum, which is equivalent to the stomach in a simple-stomached animal, and concluded that a salivary lipase, which they called pregastric esterase was primarily responsible for the hydrolysis of milk-fat in the abomasum. However, the techniques used did not rule out the possibility that part of the lipolytic activity in abomasal samples came from secretions of the mucosa of the abomasum and from pancreatic lipase in regurgitated duodenal contents.

The use of a gastric pouch avoids these difficulties, and with this technique Engstrom, Rybak, Duber \& Greenberger (I968) found very low levels of lipolytic activity in the gastric secretion of dogs. A similar procedure was used in the present studies; gastric secretion was obtained from pouches made in the fundus of the abomasum of preruminant calves, and its acid, protease and lipase contents were compared with those of abomasal contents. 


\section{EXPERIMENTAL}

\section{Animals and management}

Friesian bull calves (nos. I, 2, 3 and 4), aged 34-1 I2 d, were used, each with a separately cannulated abomasum and a highly innervated abomasal pouch. The pouch was prepared in the fundic region, which is known to be the area concerned with the secretion of acid and proteases (Hill, I970), using technique Ic of Hill \& Gregory (195I) when the calves were about I week old. The animals were offered the diets in liquid form twice daily, at 09.00 and 17.00 hours, by bucket at $37^{\circ}$.

\section{Diets}

Two milk-substitute diets, diets $A$ and $B$, based on skim-milk powder were used and contained, on a $\mathrm{g} / \mathrm{kg}$ dry matter (DM) basis, about 800 mildly preheated, spraydried skim-milk powder and 200 fat. This amount of fat was supplied in diet A as tallow $13 \circ$, coconut oil 60 and lecithin 10 , and in diet $B$ as palm oil 160 and palmkernel oil 40 . These diets, as fed, contained about II $4 \mathrm{~g} \mathrm{DM} / \mathrm{kg}$. For experiments in which diets were also placed in the pouch, diets $\mathrm{C}, \mathrm{C} / \mathrm{M}, \mathrm{C} / \mathrm{T}$ based on soya-bean flour (Sorbasoy Special; British Arkady Co. Ltd, Manchester) were used as these did not give the solid rubbery abomasal clot typical of milk-based diets and could therefore be more easily removed from the pouch. Diet $\mathrm{C}$ contained, on a $\mathrm{g} / \mathrm{kg} \mathrm{DM}$ basis, soya-bean flour 420 , whey powder 380 and fat 200 . This amount of fat was supplied as tallow 132, palm oil 56 and lecithin 12. Diet C/M differed from diet C in the source of fat which was supplied totally as milk-fat. Diets $C$ and $C / M$, as fed, contained about $140 \mathrm{~g} \mathrm{DM} / \mathrm{kg}$. Diet $\mathrm{C} / \mathrm{T}$ which was used only for introduction into the pouch was prepared by the addition of $300 \mathrm{mg}$ sodium taurocholate (BDH Ltd, Poole, Dorset) to I 1 diet C.

\section{Analytical methods}

All samples were cooled in ice immediately after collection. Details of the collection procedures for each experiment will be described later. The samples were centrifuged at $5^{\circ}$ before determining the enzymic activity of the supernatant fraction. $p H$

Determinations were made using a model $\mathrm{pHM}_{28} \mathrm{pH}$ meter (Radiometer, Copenhagen, Denmark).

\section{Lipase}

Estimations were done on the day of collection, except where stated, either by the 'pH-stat' method or colorimetrically.

I. ' $p H$-stat' method. An aqueous emulsion of tributyrin $(3 \circ \mathrm{ml} / \mathrm{l})$ was prepared freshly each day, by blending (Braun blender; Chem Lab Instruments Ltd, Hornchurch, Essex) followed by homogenization (QP homogenizer; Ormerod Engineers Ltd, Rochdale, Lancs.). Free fatty acid had previously been removed from the tributyrin by water washing or by treatment with alumina (Jensen, Marks, Sampugna, Quinn \& Carpenter, 1966) and the tributyrin stored at $5^{\circ}$ until required. The fatty 
acid released from the emulsion by the test sample at $37^{\circ}$ was determined by continuous automatic titration with $5 \mathrm{mM}$-sodium hydroxide to a fixed end-point using a pH-stat (Radiometer). 'Blank' values were obtained using diets and heated samples from the pouch and abomasum.

One unit of activity (U) is the amount of enzyme that liberates $\mathrm{I} \mu \mathrm{mol}$ fatty acid from the substrate/min. It was possible to detect levels of activity as low as $0.05 \mathrm{U}$. The maximum sample size was $5 \mathrm{ml}$.

2. Colorimetric method. For a rapid qualitative test, the sample and $p$-nitrophenylcaprylate (Popiela, Szafran \& Szafran, 1965) were shaken together in phosphate or citrate buffer (Cohen, Morgan \& Hofmann, I971) at $\mathrm{pH}_{7}$ for 10 min at room temperature, or at $37^{\circ}$ for tests at lower $\mathrm{pH}$ values. In the latter instance, nitrophenol released by the enzyme was visualized by bringing the $\mathrm{pH}$ of the cooled assay mixture rapidly to $\mathrm{pH} 7$. 'Blank' values were obtained using diets and heated samples. Results from comparative runs using the ' $\mathrm{pH}$-stat' and colorimetric methods indicated that levels of activity equivalent to $0.02 \mathrm{U}$ using the ' $\mathrm{pH}$-stat' method could be detected by the colorimetric method. The maximum sample size was $2 \mathrm{ml}$.

Pepsin (EC 3.4.23.I) and rennin (EC 3.4.23.4)

Samples that had been stored at $-25^{\circ}$ were used for these determinations. The amount of tyrosine released at $37^{\circ}$, in $15 \mathrm{~min}$, from a solution of haemoglobin powder (bovine, Type x ; Sigma Chemical Co., St Louis, Mo., USA) (20 g/l) acidified to $\mathrm{pH} 2 \cdot \mathrm{x}$ (pepsin) or 3.5 (rennin) with II M-hydrochloric acid, was estimated spectrophotometrically from the extinction at $660 \mathrm{~nm}$, after reacting $2 \mathrm{ml}$ of the filtrate with Folin and Ciocalteau's reagent (Anson, r938). Standard tyrosine (BDH Ltd) solutions $(0-0.33 \mathrm{mM})$ were prepared in $\mathrm{HCl}$ at $\mathrm{pH} \mathrm{I}$ and included for each series of estimations. One unit of activity (U) is the amount of enzyme that liberates I $\mu \mathrm{mol}$ tyrosine from the substrate/min.

\section{Lipids}

The determinations were carried out as described by Edwards-Webb (1975).

\section{Details of individual experiments}

Expt $\mathrm{I}$. Lipolytic and proteolytic activities, and $p H$ values of pouch secretion and abomasal contents. The animals were given $\operatorname{diet} \mathrm{A}$ or diet $\mathrm{B}$ for $\mathrm{I}$ or $2 \mathrm{~d}$ before sampling commenced. Pouch secretion was collected for four consecutive 15 min periods immediately after feeding or, in one instance for six $15 \mathrm{~min}$ periods, in order to obtain sufficient material for a study of lipase activity using $p$-nitrophenylcaprylate with a range of $\mathrm{pH}$ values. The abomasal contents were sampled $30 \mathrm{~min}$ after feeding. Each day's collections of pouch secretion for each animal were combined before centrifuging.

Expt 2. Lipolytic and proteolytic activities, and $p H$ values of diets held in the pouch (pouch contents). Calf no. 2 was given diet $\mathrm{C}$ and, on $2 \mathrm{~d}, 50 \mathrm{ml}$ portions of diet $\mathrm{C}$, and on I d diet $\mathrm{C} / \mathrm{T}$, at $37^{\circ}$ were placed in the pouch at various intervals after feeding (Table 2). After 10-20 min, the pouch contents (diet plus secretion) was removed almost quantitatively. 
442 Joyce Toothill, S. Y. Thompson and J. D. Edwards-Webb 1976

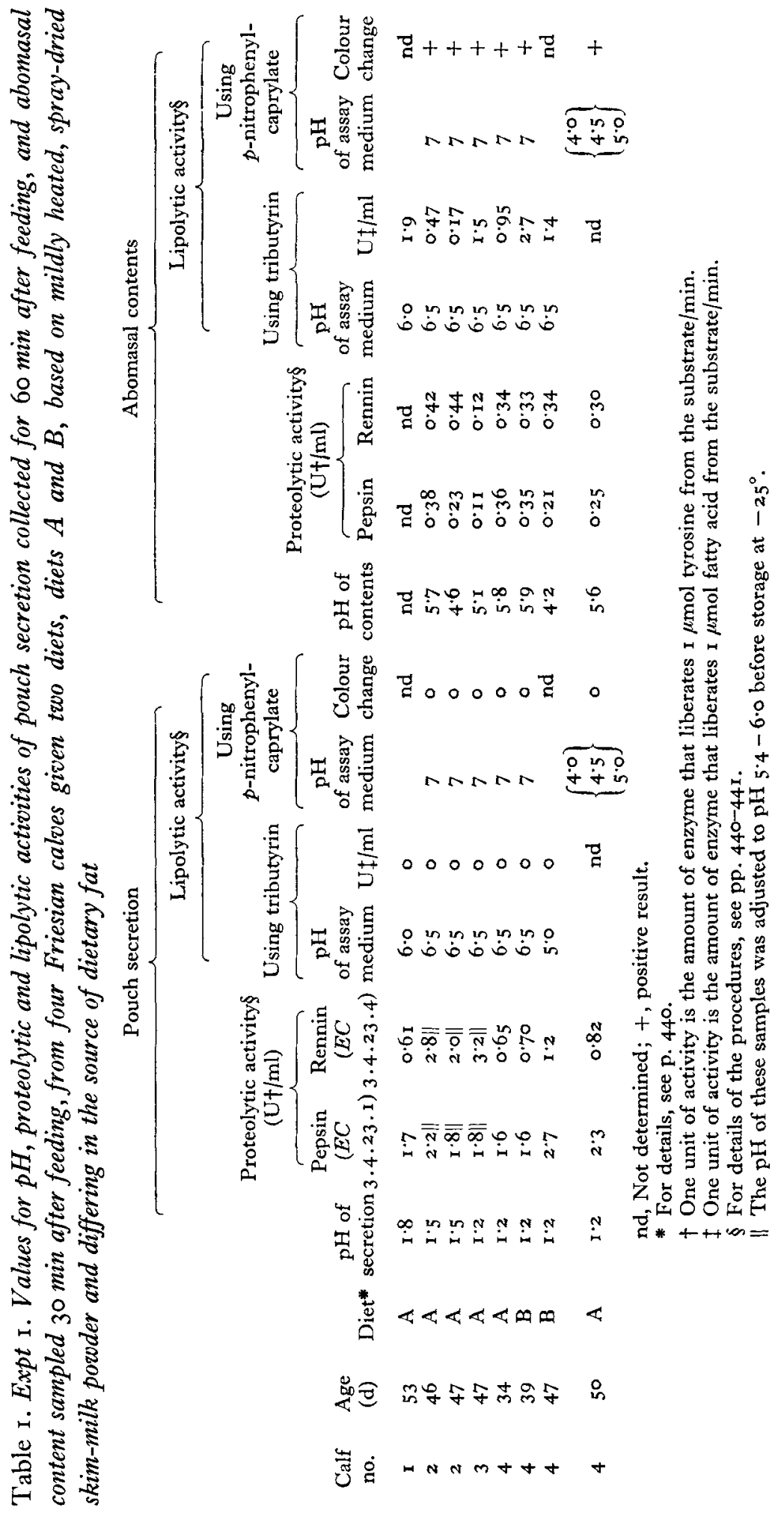


Table 2. Expt 2. Values for $p H$, proteolytic activity, and lipolytic activity using tributyrin, of pouch contents from calf no. 2, after the introduction into the pouch of two diets (diet $C$ and diet $C / T$ ) based on soya-bean flour

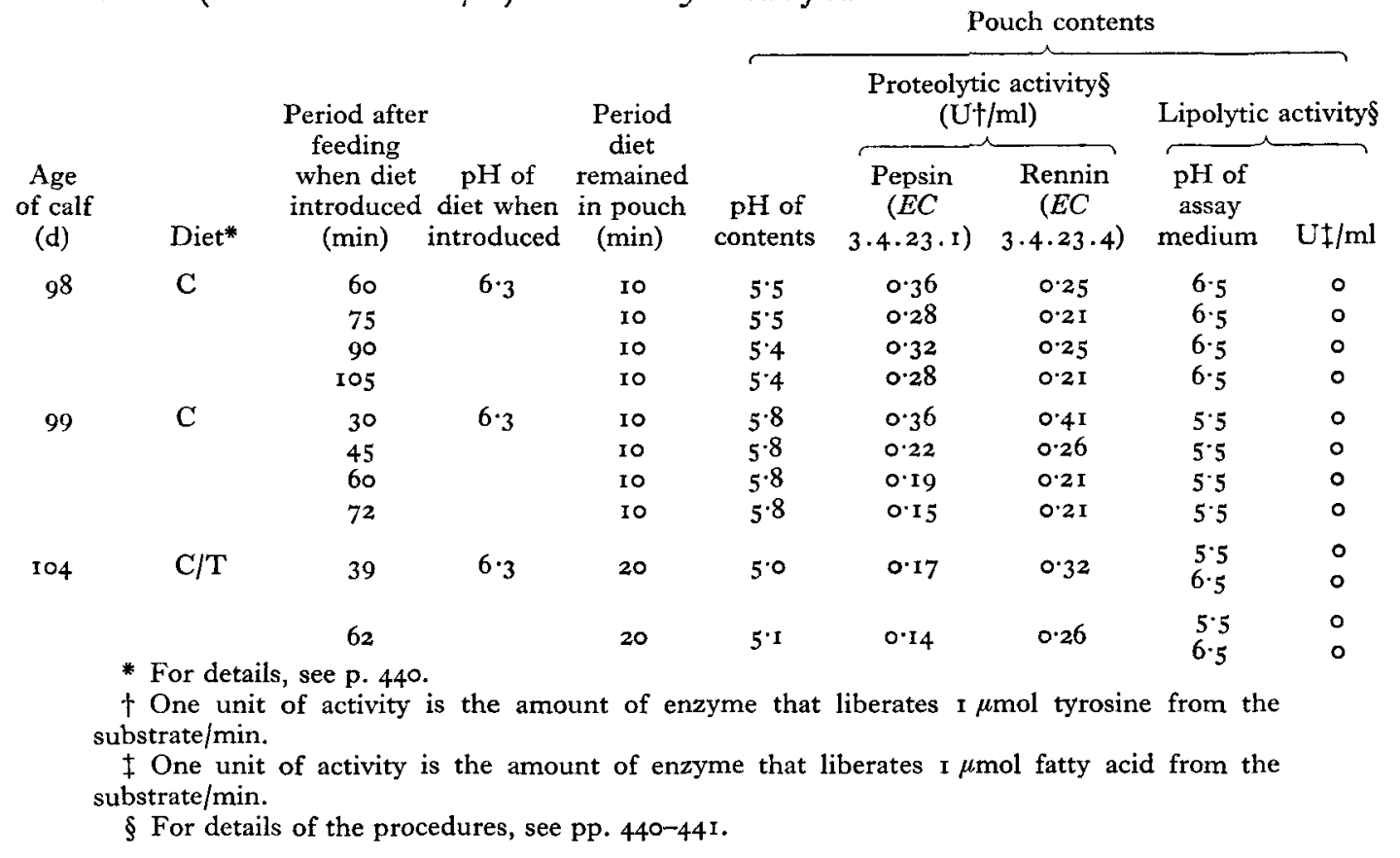

Expt 3. Lipolytic and proteolytic activities, $p H$ values and free fatty acid levels in pouch and abomasal contents. Diet $\mathrm{C}$ or $\operatorname{diet} \mathrm{C} / \mathrm{M}$ was given to calf no. 2 and $50 \mathrm{ml}$ portions of the same diet at $37^{\circ}$ were placed in the pouch and held there for $20 \mathrm{~min}$, commencing at feeding time. The abomasal contents were sampled $25,5^{\circ}$ and $60 \mathrm{~min}$ after feeding.

Expt 4. The effect of $p H$ on the lipolytic activities of abomasal contents and saliva. Lipolytic activity, using tributyrin, was measured at $\mathrm{pH} 6.5$ and 8.5 for samples that had been stored at $-25^{\circ}$. The sample of abomasal contents was from calf no. 4 and had a $\mathrm{pH}$ value of 5.8 . The saliva had been collected from a 25 -d-old Friesian bull calf which had not been operated upon, by allowing the animal to chew on a sponge moistened with reconstituted, dried skim milk. After collection, the sample of saliva was centrifuged and the $\mathrm{pH}$ of the supernatant fraction adjusted to 5.8 with $\mathrm{HCl}$.

\section{RESULTS}

Expt $\mathrm{I}$. The values for $\mathrm{pH}$, proteolytic and lipolytic activities of samples of pouch secretion and abomasal contents from four calves at different ages are given in Table $\mathrm{I}$. The $\mathrm{pH}$ values for the pouch secretions ranged from $\mathrm{I} \cdot 2$ to $\mathrm{I} \cdot 8$ and were much lower than the values ( $\mathrm{pH}_{4 \cdot 2}$ to $5^{\cdot 9}$ ) for the abomasal contents because the buffering effect of the diet was absent. Pepsin and rennin were present in all the samples of pouch secretion and abomasal contents tested. The lower level of activity 
444 Joyce Toothill, S. Y. Thompson and J. D. Edwards-Webb 1976




Table 4. Expt 3. Relative amounts of unesterified fatty acid(s) ( $\mathrm{mg} / \mathrm{g}$ fatty acids) in the soya-bean-flour-based diet containing milk-fat as the dietary fat source (diet $\left.C / M^{*}\right)$ before and after placing the diet in the pouch for $20 \mathrm{~min}$ periods, starting at o min (sample no. I) and 30 min (sample no. 2) after feeding, and in abomasal contents 25 min (sample no. I) and 50 min (sample no. 2) after feeding the diet to calf no. 2

\begin{tabular}{|c|c|c|c|c|c|}
\hline \multirow[b]{2}{*}{ Individual fatty acids: } & \multirow[b]{2}{*}{ Diet } & \multicolumn{2}{|c|}{ Pouch contents } & \multicolumn{2}{|c|}{ Abomasal contents } \\
\hline & & $\begin{array}{c}\text { Sample } \\
\text { no. I }\end{array}$ & $\begin{array}{c}\text { Sample } \\
\text { no. } 2\end{array}$ & $\begin{array}{c}\text { Sample } \\
\text { no. } 1\end{array}$ & $\begin{array}{c}\text { Sample } \\
\text { no. } 2\end{array}$ \\
\hline $4: 0$ & 9 & $\circ$ & 0 & 740 & 880 \\
\hline $8: 0$ & 22 & 0 & 28 & 300 & 350 \\
\hline I2:0 & 20 & 25 & 26 & 270 & 290 \\
\hline $16: 0$ & 15 & $\times 5$ & 16 & 70 & 76 \\
\hline 18:1 & 17 & 17 & 17 & 67 & 64 \\
\hline $\begin{array}{l}\text { Total fatty acids } \\
\begin{array}{l}(4: 0,6: 0,8: 0,10: 0, \\
12: 0,14: 0,16: 0,16: 1, \\
18: 0,18: 1,18: 2,18: 3)\end{array}\end{array}$ & 16 & 16 & 17 & 133 & 137 \\
\hline
\end{tabular}

found in the latter was probably due to dilution by the diet and saliva. V. J. Williams (personal communication) found that the proteolytic activity in the abomasal contents increased with time after feeding. Lipolytic activity, estimated using tributyrin or $p$-nitrophenylcaprylate, was present in all samples of abomasal contents but could not be detected in the pouch secretions although the $\mathrm{pH}$ values of the assay conditions were varied (Table I).

Expt 2. When diets $\mathrm{C}$ and $\mathrm{C} / \mathrm{T}$, at $\mathrm{pH} 6.3$, were introduced directly into the pouch and held there for periods of ro or $20 \mathrm{~min}$ the resulting pouch contents had $\mathrm{pH}$ values between $5^{\circ} \mathrm{O}$ and $5^{.8}$ (Table 2) due to the secretion of acid by the mucosa. Pepsin and rennin were also secreted, but no lipolytic activity could be detected.

Expt 3 . When diets $\mathrm{C}$ and $\mathrm{C} / \mathrm{M}$, initially at $\mathrm{pH} 6 \cdot 3$ or $6 \cdot 2$, were held in the pouch for $20 \mathrm{~min}$ the resulting pouch contents had $\mathrm{pH}$ values between 4.8 and $5 \cdot \mathrm{I}$ (Table 3 ). When these diets were given orally, the $\mathrm{pH}$ values of the abomasal contents were 6.I for diet C, and 4.4 and 5.3 for diet C/M. Pepsin and rennin were present in the pouch and abomasal contents, but lipolytic activity, estimated using tributyrin, $(0.65$ to $x \cdot 2 \mathrm{U} / \mathrm{ml})$ was found only in the latter. The absence of lipolytic activity in pouch contents was confirmed by the absence of any increase in the relative amounts of unesterified fatty acids compared with those in the diets, whereas in the abomasum there was marked hydrolysis, particularly when diet C/M (Table 4), which contained triglycerides richer in short-chain fatty acids than diet $\mathrm{C}$, was given.

Expt 4. Changing the $\mathrm{pH}$ value of the tributyrin substrate from 6.5 to 8.5 was found to reduce the activity of the abomasal contents sample from $\mathrm{I} \cdot 0 \mathrm{U} / \mathrm{ml}$ and that of the saliva sample from $0.54 \mathrm{U} / \mathrm{ml}$ to negligible values. 
Gastric lipolysis has been studied by taking aspirates from the stomachs of infant and adult humans (Schønheyder \& Volqvartz, 1946; Popiela et al. 1965; Cohen et al. 1971) and of calves (Ramsey \& Young, I96r), though such samples may contain saliva and regurgitated pancreatic juice. Gastric lipolysis was also reported in rats (Clark, Brause \& Holt, 1969) in which contamination of gastric contents by pancreatic lipase was prevented by diverting pancreatic flow, but saliva, which is now known to contain a lingual lipase that is active in the stomach (Hamosh \& Scow, 1973), may have been present. Uncontaminated gastric secretion can be obtained by using gastric pouches and, in this way, Engstrom et al. (1968), using dogs, found low concentrations of a lipase that hydrolysed trioctanoin but not tripalmitin.

In the present studies, although lipolytic activity was found in the abomasal contents, it could not be detected in pouch secretions even though two substrates were used which were known to be particularly susceptible to the action of lipase, i.e. tributyrin which Aldrich (1954) considered to be an excellent substrate for both lipase and esterase, and $p$-nitrophenylcaprylate which Popiela et al. (1965) found was readily hydrolysed by human gastric aspirates. In our tests, the absence of lipolytic activity in pouch secretions could have been due either to the destruction of lipase by the high acidity and high proteolytic activity of the secretion, or to the lack of a local stimulus, for Barrowman \& Darnton (1970), using histochemical techniques, found that the feeding to rats of olive oil stimulated the formation of a lipase in cells of the fundal mucosa. In order to take into account these possibilities and to simulate more closely the conditions of $\mathrm{pH}$ and proteolytic enzyme concentration within the abomasum, fat-containing diets were introduced directly into the pouch (Expts 2 and 3). However, even under these conditions no lipolytic activity was found. Inclusion of taurocholate in one of the diets (Expt 2) to simulate conditions that would occur in the abomasum after regurgitation of duodenal contents was also without effect. As lipolytic activity was found (Tables I and 3) in samples of abomasal contents with $\mathrm{pH}$ values and protease levels comparable to those of some of the pouch contents samples (Tables 2 and 3 ), and also in samples of abomasal contents in which the $\mathrm{pH}$ values were slightly lower, and in which conditions for proteolysis may therefore have been more favourable than in the pouch contents, it seems unlikely that there would have been total destruction in the pouch contents of any lipase that may have been secreted. However, no lipolysis could be detected, even though the volumes of pouch contents used for the assays with tributyrin were five to ten times greater than corresponding volumes of abomasal contents. There was also no evidence that pouch contents interfered with our test for lipase, as its addition to abomasal contents did not reduce the hydrolysis of tributyrin.

Grosskopf ( 1965$)$ found that the $\mathrm{pH}$ optimum for the hydrolysis of tributyrin by salivary lipase was between 4.5 and 6.0 , in contrast to that of 8.0 for pancreatic lipase (Schønheyder \& Volquartz, 1945). In the present work, the absence of a lipolytic enzyme in the secretion of the pouch and the extremely low activity of 
abomasal contents and saliva at $\mathrm{pH} 8.5$ compared with that at $\mathrm{pH} 6.5$ (Expt 4 ) suggest that the enzyme present in the abomasum comes from the saliva and not from pancreatic lipase in regurgitated duodenal contents. The presence of a lipolytic enzyme in tissues of, and around, the root of the tongue, and in the submaxillary salivary gland of calves which was active against 2-naphthyl-laurate and -palmitate has been reported by Ramsey, Wise \& Tove (I956).

It is considered that the use in the present work of the abomasal pouch technique, which prevents contamination of the abomasal secretions by saliva or duodenal contents, has indicated conclusively that if a lipolytic enzyme is secreted by the fundal abomasum, it can only be present at an extremely low level. It would appear, therefore, that the lipolysis of triglycerides in the abomasum of the preruminant calf is due predominantly to a lipolytic enzyme in the swallowed saliva (Ramsey \& Young, 1961; Otterby et al. 1964a,b) and not to a lipase in abomasal secretion.

The authors thank Dr J. H. B. Roy, Mr V.J. Williams, Dr H. L. Buttle and Miss C. M. Gillies for the preparation and care of the calves, and Mr A. Walder for skilled technical assistance.

\section{REFERENCES}

Aldrich, W. N. (1954). Biochem. F. 57, 692.

Anson, M. L. (1938). F. gen. Physiol. 22, 79.

Barrowman, J. A. \& Darnton, S. J. (I970). Gastroenterology 59, 13.

Clark, S. B., Brause, B. \& Holt, P. R. (1969). Gastroenterology 56, 214.

Cohen, M., Morgan, R. G. H. \& Hofmann, A. F. (1971). Gastroenterology 6o, 1.

Edwards-Webb, J. D. (1975). F. Sci. Fd Agric. 26, 1943.

Engstrom, J. F., Rybak, J. J., Duber, M. \& Greenberger, N. J. (1968). Am. J. med. Sci. 256, 346.

Grosskopf, J. F. W. (1965). Onderstepoort J. vet. Res. 32, 153.

Hamosh, M. \& Scow, R. D. (1973). F. clin. Invest. 52, 88.

Hill, K. J. (1970). In Duke's Physiology of Domestic Animals, 8th ed., p. 38 [M. J. Swenson, editor]. Ithaca NY: Cornell University Press.

Hill, K. J. \& Gregory, R. A. (195I). Vet. Rec. 63, 647.

Jensen, R. G., Marks, 'T. A., Sampugna, J., Quinn, J. G. \& Carpenter, D. L. (1966). Lipids r, 45 I.

Otterby, D. E., Ramsey, H. A. \& Wise, G. H. (r964a). F. Dairy Sci. 47, 993.

Otterby, D. E., Ramsey, H. A. \& Wise, G. H. (rg64b). F. Dairy Sci. 47, 997.

Popiela, T., Szafran, H. \& Szafran, Z. (1965). Clinica chim. Acta I1, 283.

Ramsey, H. A., Wise, G. H. \& Tove, S. B. (1956). F. Diary Sci. 39, I312.

Ramsey, H. A. \& Young, J. W. (r96r). F. Dairy Sci. 44, 2227.

Schønheyder, F. \& Volqvartz, K. (1945). Acta physiol., scand. ro, 62.

Schønheyder, F. \& Volqvartz, K. (1946). Acta physiol., scand. I1, 349. 